\title{
XI. Observations on the manufacture of the acetite of copper or verdigrise, Verdet, \&c.
}

\section{J.A. Chaptal}

To cite this article: J.A. Chaptal (1799) XI. Observations on the manufacture of the acetite of copper or verdigrise, Verdet, \&c. , Philosophical Magazine Series 1, 4:13, 71-79, DOI: $10.1080 / 14786449908677032$

To link to this article: http://dx.doi.org/10.1080/14786449908677032

曲 Published online: 18 May 2009.

Submit your article to this journal \lceil

Џ Article views: 2

Q View related articles $\sqsubset$ 
4. Having found thefe tranfitions, or any others, in fome mountains, if they are not then found in other mountains, you mult examine whether their abfence does not arife from their having been deftroyed; veltiges of them are to be fought for; and if it appears that they never exifted, you muft endeavour to difcover, in the nature and pofition of the mountains, what may have been the caufe of their abfence*.

[To be continued.]

XI. Obfervations on the Manxfacture of the Acetite of Copper or Verdigrife, Verdet, \&ec. By J. A. Chaptax.†

$\mathrm{T}$

HE acetite of copper is one of the preparations of that metal moft frequently ufed in the arts. It is not only one of the principal refources of painting, but upon many occafions is employed with great advantage in dyeing. Almoft all the oxydes of copper obtained by the action of faline fubftances have a blue colour, more or lefs inclining to green, and almoft all the neutral falts corrode the metal, and produce that oxyde which is called verdigrife. It is fufficient to bring them into contact with the copper, or to immerfe the metallic plates in a faline folution, and afterwards to expofe them to the air to dry.

Thofe aeids which oxydate the copper by their decompofition, produce an effect like that of neutral falts. The oxyde is of a foft blueilh-green colour; their action is fo fpeedy, that if the copper be expofed to the vapour of them for fome minutes its furface will be immediately oxydated. The oxygenated muriatic acid produces that effect as well as the vapour of the nitric acid, and even thofe of the fulphuric acid. A phenomenon which cannot efcape the eye of an

* The beft method of oblerving mountains, in order to acquire a thorough knowledge of them, is, not to confine onefelf merely to follow the valleys, but to interfeet alfo, as much as poffible, the principal chains and the branches detached from them in the direction of their breadth. $C$.

+ From Annales de Chimie, No. LXXV. 
obferver, is, that the oxydes of copper obtained by fire are very different from thofe produced by the decompofition of acids on that metal. The colour of them is grey, inftead of being green; and when the calcination is continued a long time at a violent heat, they may be concentrated to a red oxyde of a blood colour. This phenomenon was obferved by Kunckel in his chemical laboratory.

Saline fubftances are not the only ones capable of oxydating copper green. All.oils and fat matters produce the fame effect. Even water, when left for a confiderable time in copper veffels, caufes an oxydation. But what will appear very extraordinary is, that the greater part of thefe fubftances have no fenible effect upon copper, except when cold. Thofe falts even which corrode that metal when left at reft in veffels, do not attack it in fo fenfible a manner when in a frate of ebullition.

Of all the preparations of copper by oxydation, there is none more valuable than that made by vinegar. All the verdigrife ufed in commerce is prepared by that acid; and it is at Montpellier in particular and in the neighbourhood, that the manufactories of it are eftablifhed. In the Memoirs of the Academy of Paris for 1750 and 1753 , may be feen a very exact defcription of the procefs then followed at Montpellier. for making verdigrife; but as that procefs bas been much improved, and as at prefént the hulks of grapes are employed inftead of the ftalks, a method far more economical, fince wine is no longer ufed, the following account of the manner of manufacturing verdigrife, as now practifed, may be of utility to the public.

The firt materials ufed for this purpofe are copper and the hufks or kins of grapes left after the laft prefling. The copper employed was formerly all imported from Sweden; but at prefent it is brought from different foundries eftablifhed at Saint Bel, Lyons, Avignon;Bedarieux, Montpellier, \&c. It is in round plates half a line in thicknefs, and from wenty to twenty-five inches in diameter. Each plate at 
Montpellier is divided into twenty-five laminæ, forming almoft all oblong fquares of from four to fix inches in length; three in breadth, and weighing about four ounces. They are beat feparately with the hammer on an anvil to fmooth their furfaces, and to give the copper the neceffary confiftence. Without this precaution it would exfoliate, and it would be more difficult to fcrape the furface in order to detach the oxydated cruft. Befides this, fcales of pure metal would be taken off, which would haften the confumption of the copper.

The hulks of grapes, known at Montpellier under the name of racque, were formerly thrown on the dung-hill after the poultry had picked out the fmall ftones contained in them. At prefent they are preferved for making verdigrife, and fold at the rate of from fifteen to twenty livres per muid. The preparation of them is as follows: After the vintage is finifhed, the hufks are fubjected to the prefs, in order to extract all the wine with which they may be impregnated, and they are then put into vats, where they are preffed down with the feet to fill up all the vacuities and render the mafs as compact as poffible. The coverings of thefe vats are carefully faftened down, and they are preferved for ufe in a dry cool place.

Thefe hu1ks are not always of the fame quality: when the grapes contain little of the faccharine matter, when the feafon has been rainy, the fermentation incomplete, or when the wine is not generous, the hufks are attended with feveral faults. I. They are difficult to be preferved, and there is great danger of their foon being fpoilt. 2. They produce very little effect, cannot be eafily heated, fend forth very little of the acetous odour, and make the plates of copper fweat without thewing efflorefcence on their furface. Independently of the nature of the grapes and the ftate of the wine, the quality of the hufks varies alfo according as they have been expreffed with more or lefs care. Hurks which have not been much preffed, produce a far greater effect than thofe which have been dried. To explain their different effeets, 
it will be fufficient to obferve that their action is proporioned to the quantity of wine they retain, as it is that liquor alone which can pafs to the ftate of vinegar. When the husks therefore are deftined for a verdigrife manufactory, care muft be taken to exprefs them only weakly, in order to preferve more of their acidifiable principle.

When a fufficient quantity of copper and of hufks has: been provided, nothing remains but to proceed to the operations, which are generally performed in cellars. They may be performed alfo on a ground floor if it be fomewhat damp, if the temperature be fubject to little variation, and if there be not too much light. The firit operation is to make the hufks ferment, which is called avina. For that purpofe one of the vats is opened, and the hufks are put into two others of equal fize, taking care to expofe them as little as poffible to the air, and not to comprefs them. One vat full of hulks ought to fill two, and to occupy a double fpace after this operation. In fome manufactories the hufks contained in a vat are diftributed into twenty or twenty-five earthen veffels or jars called oules, and which are generally fixteen inches in height, fourteen in diameter at the belly; and about twelve at the mouth. When the hufks have been put into thefo veffels, they are covered by putting the: lid merely on the opening without preffing it down. The covers are of ftraw, and made for that purpofe. In this ftate the hufks foon heat; and this change may be known by thrufting the hand into them, and by the four fmell which they begin to exhale. The fermentation firft takes place at the bottom of the veffel, and gradually afcending extends itfelf to the whole mafs. It proceeds to $3^{\circ}$ or 35 degrees of Reaumur.

At the end of three or four days the heat decreafes, and at length ceafes entirely; and as the manufacturers apprehend. the lofs of a portion of the vinegar by the natural effect of a heat too much prolonged, they take care after three days fermentation to remove the hufks from the fermenting veffels, in order that they may fooner cool. Thofe who employ vats 
remove them into jars, and thofe who ufe jars put them into others. Befides the lofs of the acetous fpirit, too great heat inclines the mafs at the bottom of the veffel to become mouldy; which renders it unfit for making verdigrife. Some manufacturers, to increafe the effect of the hufks, form them into heaps, which they befprinkle with generous wine before they bring them to ferment.

The fermentation does not always take place at the fame time, nor with the fame energy. Sometimes it commences in twenty-four hours, and fometimes it has not begun at the end of three weeks. The heat fometimes will rife to fuch a height that the hand cannot be kept in the mafs, and that the acetous odour is fo ftrong that one can hardly approach the veffels; while at others the heat is hardly fenfible, and foon vanifhes. There are even inftances of the hulks becom. ing putrid and mouldy without turning acid. The fermentation is affifted and promoted by raifing the heat of the place by means of chafing-dinhes, by covering the veffels with cloths, by fhutting the doors, and by airing the mafs with more care. The differences in the fermentation depend, x. On the temperature of the air: in fummer the fermentation is fpeedier. 2. On the nature of the hufks: thofe which arife from very faccharine grapes heat more eafily. 3. On the volume of the mafs: a larger mafs ferments fooner, and with more ftrength, than a fmall one. 4. On the contact of the air : the beft aired hufks ferment beft.

At the fame time that the hufks are made to ferment, a preliminary preparation called defafouga is given to the plates of copper which are ufed for the firft time. This operation is not employed for thofe which have been already ufed, and confifts in diffolving verdigrife in water in an earthen veffel, and rubbing over each plate with a piece of coarfe linen dipped in this folution. The plates are then immediately placed clofe to each other, and left in that manker to dry. Sometimes the plates are only laid on the 
top of the fermented hưks, or placed under thofe which have been already ufed for caufing the copper to oxydate. It has been obferved, that when the operation called defafouga has not been employed, the plates grow black at the firf operation, inftead of becoming green.

When the plates are thus prepared, and the hufks have been brought to ferment, the workmen try whether the latter are proper for the procefs, by placing under them a plate of copper, and leaving it buried there for twenty-four hours. If the plate of copper, after this period, is found covered with a fmooth green cruft, in fuch a maniner that none of the metal appears, they are then thought fit for being difpofed in layers with the copper. On the other hand, if drops of water are obferved on the furface of the plates, the plates are faid to fweat, and it is concluded that the heat of the hufks has not fufficiently fubfided. They confequently defer making another trial till the next day. When they are affured that the huks are in a proper ftate, they form them into layers in the following manner :

The plates are all put into a box, which, inftead of having a bottom, is divided in the middle by a wooden grate. The plates difpofed on this grate are fo ftrongly heated by a chafing-difh placed under them, that the woman employed in this labour is fometimes obliged to take them up with a cloth; in order that the may not burn her hands. As foon as they have acquired that heat, they are put into the jars in layers with the hufks. Each jar is then clofed with a covering of fraw, and left to oxydate. This period is called coüa, to hatch. Thirty or forty pounds of copper, more or lefs according to the thicknefs of the plates, are put into each jar. At the end of ten, twelve, fifteen, or twenty days, the jar is opened; and if the hurks are white, it is time to take out the plates. The cryftals are then feen detached, and of a flky appearance on their furface. The hulks are thrown back, and the plates are put in what is called relai. For that pur- 
pofe they are immediately depofited in a corner of the cellar on fticks ranged on the floor. They are placed in an upright pofition, one leaning againft the other; and at the end of two or three days they are moiftened, by taking them up in handfulls and immerfing them in water in earthen pans. "They are depofited quite wet in their former pofition, and left there for feven or eight days; after which they are once or twice immerfed again. This immerfion and drying are renewed fix or eight times, every feven or eight days. As the plates formerly were put into wine, thefe immerfions were called one wine, two wines, three wines, according to the number of times. By this procefs the plates fwell up, the green is nourifhed, and a coat of verdigrife is formed on all their furfaces, which may be eafily detached by fraping them with a knife.

Each jar furnithes five or fix pounds of verdigrife at each operation. It is then called freth verdigrife, moift verdigrife, \&c. This verdigrife is fold in that ftate by the manufacturers to people who dry it for foreign exportation. In this firft ftate it is only a pafte, which is carefully pounded in large wooden troughs, and then put into bags of white leather; a foot in height and ten inches in diameter. The te bags are expofed to the air or the fun, and are left in that fate till the verdigrife has acquired the proper degree of drynefs. By this operation it decreafes about fifty per cent., more or lefs according to its primitive ftate. It is faid to ftand proof by the knife, when the point of that inftrument pufhed againft a cake of verdigrife through the fkin cannot penetrate it.

The plates of copper which have been alreatly ufed are again employed for the fame operation, till they are almoft completely confumed. Inftead of heating them artificially, as above mentioned, they are fometimes expofed only to the fun. The fame plates will ferve fometimes for ten years, but they are often worn out in two or three. This, however, depends 
depends on the quality of the copper. That which is extremely fmooth, well beat, and very compact, is always moft efteemed.

Formerly moift verdigrife could not be fold till its quality had been previoufly afeertained; and for that purpole it was carried to a public warehoufe, where it was fold after that point had been determined.

By comparing this procefs with that defcribed by Montet, it will be found that the changes introduced are much in fávour of the new. Formerly the workmen took the ftalks of the grapes dried in the fun, and began by immerfing them for eight days in vinaffe (the refiduum of the diftillation of wine for making brandy). They then fuffered the moifture to drain off through a baket, after which they put about four pounds into a jar, and poured over them three or four pints of wine. The ftalks were made to imbibe a large portion of the wine, by ftirring them ftrongly with the hand; the jar was then covered, and the ftalks were fuffered to ferment. The fermentation commenced fooner or later, according to the nature of the wine and the temperature of the air. But after it had once begun, the wine became turbid, and exhaled a frong odour of vinegar. At length the heat decreafed, and the ftalks were then taken out and the wine was drawn off. When the ftalks were a little drained, they were difpofed in layers with the plates of copper, and the operation was continued in the fame manner as with the hufks. When the plates were taken from the jars to be put in relai, inftead of immerfing them in pure water, as is done at prefent, they were moiftened three or four times with four wine, which was called giving them three or four wines.

It may be eafily feen that there is a great faving in the procefs followed at prefent, fince the manufacturers no longer ufe wine, which enhanced the price of the verdigrife. Some have condemned, in the new procers, the practice of ufing the copper too foon; bat this objection fell to the ground, 
when it was obferved that the verdigrife obtained was in proportion to the copper corroded; and what proves that this method is more advantageous, is, that all the manufacturer have abandoned the old method and adopted the new *.

XII. On the Metbod of preparing Tallow Candles with Wooden Wicks. By Profefor Medicus of Heidelbergt.

" Hor feveral years paft tallow candles with wooden wicks have been prepared, in large quantities, by the candlemakers at Munich, and much ufed in that neighbourhood. $I$ have burnt them during the whole winter, and never wifh to ufe any other kind, as they are attended with feveral advantages which common tallow candles do not poffefs. They afford about the fame quantity of light as a wax candle; burn alfo with great fteadinefs and uniformity, and never crackle or rùn. The candle-makers here keep the method of preparing thefe candles as fecret as they can; but I fhall communicate to the public what I have been able to learn refpecting the procefs.

"The only difference between thefe candles and the common tallow candles is, that the ground work of the wick confifts of a very thin nip of wood, bound round to a confiderable thicknefs with very fine unfpun cotton; but in fuch a manner that the fize of the wick does not much exceed that of the wick of a common candle. The cotton is wound round the wick by the hand; but in general it is done by means of a reel, which I have not yet been able to fee. The thin nips of wood are furnithed to the candlemakers by the country people, and, if we may judge from

* There are no large manufaetories of vcrdigrife at Montpellier ; but each family makes a certain quantity, and the operations are in general performed by women.

† From Riems Neue Samminng Qekonomifcber Scbrifien, part xii. 